\title{
Altered Structural and Functional Synaptic Plasticity with Motor Skill Learning in a Mouse Model of Fragile X Syndrome
}

\author{
Ragunathan Padmashri, ${ }^{\star}$ Benjamin C. Reiner, ${ }^{\star}$ Anand Suresh, ${ }^{\star}$ Elizabeth Spartz, and Anna Dunaevsky \\ Department of Developmental Neuroscience, Munroe-Meyer Institute, University of Nebraska Medical Center, Omaha, Nebraska 68198-5960
}

Fragile X syndrome (FXS) is the most common inherited intellectual disability. FXS results from a mutation that causes silencing of the FMR1 gene, which encodes the fragile X mental retardation protein. Patients with FXS exhibit a range of neurological deficits, including motor skill deficits. Here, we have investigated motor skill learning and its synaptic correlates in the fmr 1 knock-out (KO) mouse. We find that fmr1 KO mice have impaired motor skill learning of a forelimb-reaching task, compared with their wild-type (WT) littermate controls. Electrophysiological recordings from the forelimb region of the primary motor cortex demonstrated reduced, training-induced synaptic strengthening in the trained hemisphere. Moreover, long-term potentiation (LTP) is impaired in the fmr $1 \mathrm{KO}$ mouse, and motor skill training does not occlude LTP as it does in the WT mice. Whereas motor skill training induces an increase of synaptic AMPA-type glutamate receptor subunit 1 (GluA1), there is a delay in GluAl increase in the trained hemisphere of the $\mathrm{fmr} 1 \mathrm{KO}$ mice. Using transcranial in vivo multiphoton microscopy, we find that $\mathrm{fmrl} \mathrm{KO}$ mice have similar spine density but increased dendritic spine turnover compared with WT mice. Finally, we report that motor skill training-induced formation of dendritic spines is impaired in fmrl KO mice. We conclude that FMRP plays a role in motor skill learning and that reduced functional and structural synaptic plasticity might underlie the behavioral deficit in the fmrl KO mouse.

\section{Introduction}

Fragile X syndrome (FXS) is the most common inherited form of an intellectual disability with a prevalence rate of $>1: 4000$ (Penagarikano et al., 2007). FXS results from a mutation that causes silencing of the FMR1 gene, which encodes the fragile X mental retardation protein (FMRP; Pieretti et al., 1991). FMRP is an RNA-binding protein that is involved in regulating the translation of neuronal proteins and is thought to be important for some forms of synaptic plasticity (Pfeiffer and Huber, 2009; Darnell et al., 2011). Patients with FXS exhibit a range of neurological deficits, including cognitive impairments, social anxiety, seizures, sleep disorders, and motor skill deficits (Koekkoek et al., 2005; Zingerevich et al., 2009; Van der Molen et al., 2010). Although less attention has been given to studying these motor impairments, motor skills are integral to exploration, imitation (Vanvuchelen et al., 2007), communication (Gernsbacher et al., 2008), and other skills with which children with FXS struggle. Therefore, interventions targeted at motor impairments may be important

\footnotetext{
Received April 6, 2013; revised Nov. 6, 2013; accepted Nov. 11, 2013.

Author contributions: A.D. designed research; R.P., B.C.R., A.S., and E.S. performed research; R.P., B.C.R., and A.S. analyzed data; A.D. wrote the paper.

This work was supported by a National Institute of (hild Health and Human Development R01 HD67218 (to A.D.). We thank Yoosun Jung for maintaining the mouse colony and Guru Pendyala for his assistance with the biochemistry experiments, and Drs R. Halloworth and S. Bonasera for comments on the paper.

${ }^{*}$ R.P., B.C.R., and A.S. contributed equally to this work.

Correspondence should be addressed to Dr Anna Dunaevsky, Developmental Neuroscience, Munroe-Meyer Institute, University of Nebraska Medical Center, 985960 Nebraska Medical Center Omaha, NE 68198-5960. E-mail: adunaevsky@unmc.edu.

DOI:10.1523/JNEUROSCI.2514-13.2013

Copyright $\odot 2013$ the authors $\quad 0270-6474 / 13 / 3319715-09 \$ 15.00 / 0$
}

in addressing the core areas of impairment in this neurodevelopmental disorder.

Motor skill learning requires the involvement of multiple brain regions, such as the cerebellum, basal ganglia, and the motor cortex (Shmuelof and Krakauer, 2011). Synaptic plasticity in the primary motor cortex (M1) has been shown to be particularly important. Previous experiments support this by demonstrating that motor skill learning: (1) enhances the synaptic responses of intracortical connections in the M1 (Rioult-Pedotti et al., 1998; Hodgson et al., 2005); (2) occludes long-term potentiation (LTP) in these connections (Rioult-Pedotti et al., 2000, 2007; Hodgson et al., 2005), a leading candidate mechanism for persistent changes in synaptic strength; and (3) induces structural modification of M1 dendritic spines, sites of excitatory synaptic input (Harms et al., 2008; Xu et al., 2009; Fu et al., 2012).

The fmrl knock-out (KO) mouse recapitulates several behavioral and physical characteristics observed in FXS (The DutchBelgian Fragile X Consortium, 1994; Comery et al., 1997; Koekkoek et al., 2005; Budimirovic and Kaufmann, 2011; Vinueza Veloz et al., 2012), including deficits in associative motor learning (Vinueza Veloz et al., 2012), yet the accompanying synaptic changes have not yet been analyzed in this mouse. To gain a better understanding of how FMRP contributes to regulation of synaptic plasticity in the M1, we trained $f m r 1 \mathrm{KO}$ mice and wildtype (WT) littermate control mice on a single forelimb reaching task and analyzed structural and functional synaptic plasticity. We report that the fmrl KO mice display a motor skill learning deficit. Field potential recordings from the forelimb region of M1 demonstrated reduced, training-induced synaptic strengthening 
in the trained hemisphere. Moreover, LTP is impaired in the fmrl $\mathrm{KO}$ mouse, and motor skill training does not occlude LTP as in the WT mice. Although motor skill training induces a transient increase of synaptic AMPA-type glutamate receptor subunit 1 (GluA1), in the trained hemisphere of WT mice, in the fmrl KO mice there is a temporal dysregulation of synaptic GluA1 translocation with training. Finally, using transcranial in vivo multiphoton microscopy, we find that training-induced formation of dendritic spines is impaired in fmrl KO mice. We conclude that FMRP plays a role in motor skill learning and that altered functional and structural synaptic plasticity might underlie the behavioral deficit in the fmrl $\mathrm{KO}$ mice.

\section{Materials and Methods}

Animals. Mice were cared for in accordance with NIH guidelines for laboratory animal welfare. All experiments were approved by the University of Nebraska Medical Center Institutional Animal Care and Use Committee. Male C57BL/6 fmrl KO and littermate control mice were used for behavioral and electrophysiology experiments. $\mathrm{Tg}$ (Thyl-YFP)HJrs/J (The Jackson Laboratory) males were crossed with C57BL/6 fmr 1 heterozygous females. Male YFP-expressing fmrl KO and littermate control mice were used for imaging experiments.

Motor skill training. Five- to 6-week-old mice were food-restricted ( $85 \%$ of their free-feeding weight). Mice were placed in a cage with a thin slit on the front wall (Fig. 1A). Mice were trained to reach through the slit with their preferred forelimb and grasp and retrieve individual food pellets. There is a $4 \mathrm{~mm}$ gap between the platform that holds the food pellets and the slit, preventing the mice from sliding the food pellets toward them. An initial pretraining session determined forelimb preference, and pellets were then placed on the side that enabled the use of the preferred forelimb only. Mice had one training session per day that lasted 30 min or 100 reaches. Motor skill performance was quantified by the success rate (percentage of successful retrievals). The trained hemisphere $(\mathrm{tr})$ is contralateral to the trained forelimb and the untrained hemisphere (utr), acts as an internal control.

Electrophysiology. Coronal cortical slices $(400 \mu \mathrm{m})$ containing the forelimb representation of the M1 (Tennant et al., 2011), were prepared in artificial CSF (ACSF) as previously described (Harms et al., 2008). Slices were prepared $12-15 \mathrm{~h}$ after the last training session, and the experimenters were blind to the genotype and the identity of the trained forelimb. Tungsten bipolar stimulation electrodes were placed in upper layer $2 / 3,1.5-1.8 \mathrm{~mm}$ lateral to the midline (Tennant et al., 2011), and recording electrodes were placed $400 \mu \mathrm{m}$ medial to the stimulation electrode. Extracellular field potentials (FPs) were evoked by $0.2 \mathrm{~ms}$ pulses at $0.03 \mathrm{~Hz}$. Peak amplitudes of the negative-going FPs were used as a measure of synaptic strength (Hess et al., 1996). Stimulation intensities were adjusted until a response of $0.2 \mathrm{mV}$ was recorded, which was defined as the threshold intensity, and multiples of this intensity were used for determination of input-output relationships (Rioult-Pedotti et al., 1998).

Chemical LTP (cLTP) was induced by bath application of bicuculline $(6.3 \mu \mathrm{M})$ for $3 \mathrm{~min}$, followed by forskolin $(50 \mu \mathrm{M})$ and the phosphodiesterase inhibitor rolipram $(0.1 \mu \mathrm{M})$ in $\mathrm{Mg}^{2+}$-free ACSF for $15 \mathrm{~min}$. Stimulation intensity that elicited a half maximal response was used for the cLTP experiments.

Synaptosomal preparations. Synaptosomes were prepared as previously described (Weiler et al., 1981). Two coronal slices $(750 \mu \mathrm{m})$ containing the forelimb M1 were cut on a vibratome (Leica), and the forelimb region of the M1 was dissected out. For biotinylation experiments, trained or untrained forelimb M1 regions were pooled from 2 to 3 mice to yield 15-22 mg of tissue. The tissue was then homogenized in sucrose medium
B

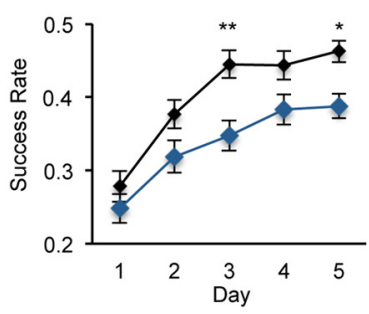

C

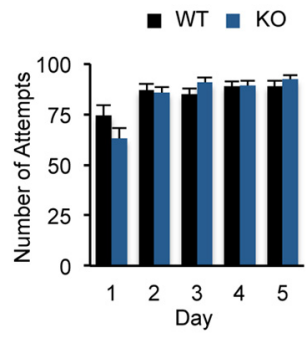

Figure 1. Impaired motor skill learning in the $\mathrm{fmr} 1 \mathrm{KO}$ mouse. $\boldsymbol{A}$, An illustration of the training box with a mouse reaching out formed by the KO and WT mice at any of the training days. mean \pm SEM. ${ }^{*} p<0.05,{ }^{* *} p<0.01$.

(0.32 $\mathrm{m}$ sucrose, $10 \mathrm{~mm}$ HEPES, and $1 \mathrm{~mm}$ EDTA) using a hand-held homogenizer. The homogenate was spun at $1500 \mathrm{rpm}$ for $10 \mathrm{~min}$ at $4^{\circ} \mathrm{C}$. The supernatant was then spun at $13,300 \mathrm{rpm}$ for $15 \mathrm{~min}$ at $4^{\circ} \mathrm{C}$, to separate the synaptosomal fraction. This was resuspended in ACSF and its protein concentration was determined. Synaptosomal preparations were used for measurements of total synaptic GluA1 or for surface synaptic GluA1 using a biotinylation assay. Equal protein quantities of synaptosomes were biotinylated.

Surface biotinylation assay. Surface protein expression in synaptosomal samples was detected through a biotinylation assay, followed by a Western blot analysis with antibodies directed against GluA1. Synaptosomal preparations were washed and incubated in Sulfo-NHS-SS biotin $\left(0.5 \mathrm{mg} / \mathrm{ml}\right.$ in ACSF, Pierce) for $1 \mathrm{~h}$ at $4^{\circ} \mathrm{C}$. Surface biotinylation was stopped by removing the solution, followed by quenching of unbound biotin with cold $100 \mathrm{~mm}$ glycine in ACSF for $5 \mathrm{~min}$, three times. Synaptosomes were lysed in RIPA buffer ( $50 \mathrm{~mm}$ Tris. $\mathrm{HCl}, 25 \mathrm{~mm} \mathrm{NaCl}, 0.1 \%$ SDS, $0.5 \%$ Na deoxycholate, $1 \%$ Triton X-100, and 0.5 м EDTA). Biotinylated proteins $(400 \mu \mathrm{g})$ were precipitated with $200 \mu \mathrm{l}$ of neutravidin beads (Pierce) overnight at $4^{\circ} \mathrm{C}$. The beads were washed $(3 \times)$ and bound protein was eluted by boiling in Lammeli buffer for $10 \mathrm{~min}$. The eluate was separated on 4-15\% Biorad Mini-Protean TGX Precast SDS-PAGE gels, and transferred to polyvinyl difluoride membranes. The membranes were probed with anti-GluA1 (1:1500, Millipore) and anti-GAPDH (1: 4000, Cell Signaling Technology). The membranes were incubated with horseradish peroxidase-conjugated secondary antibodies (anti-rabbit 1:5000), and bands were visualized using a Cell Biosciences FluroChem HD2 system. Because we used a crude synaptosomal preparation, GAPDH was abundant in the biotinylated samples. Hence, we used GAPDH as a loading control.

Cranial windows. Thinned-skull cranial windows were prepared above the forelimb region of the M1 in one hemisphere per animal. A rectangular window measuring $1.5 \mathrm{~mm}$ wide by $1.0 \mathrm{~mm}$ long was prepared with the corner closest to bregma being positioned at $750 \mu \mathrm{m}$ laterally. Briefly, mice were anesthetized with a ketamine/dexdormitor mixture (100 $\mathrm{mg} / \mathrm{ml}$ and $0.5 \mathrm{mg} / \mathrm{ml}$ respectively, $2.5 \mathrm{ml} / \mathrm{Kg}$ ). Following a midline incision, the skull first was thinned using a high-speed dental drill, with frequent breaks for the application of a saline cooling solution. Final thickness was achieved by hand-thinning using a dental microblade (Surgistar). The window was covered by suturing the skin in between imaging sessions, and was rethinned before imaging on the next day. Animals were revived from anesthesia with Antisedan (atipamezole hydrochloride $5.0 \mathrm{mg} / \mathrm{ml}, 0.2 \mathrm{mg} / \mathrm{ml}$ ketamine/dexdomitor mixture used).

Imaging. All imaging was performed with a multiphoton microscope (Moving Objective Microscope, MOM; Sutter), using a Ti:sapphire laser (Chameleon Vision II, Coherent) tuned to $925 \mathrm{~nm}$. Images were collected with a Nikon water-immersion objective $(60 \times, 1.0 \mathrm{NA})$. Excitation power measured at the back aperture of the objective was typically $\sim 30 \mathrm{~mW}$ and was adjusted to achieve near identical levels of fluorescence for each imaged region using a Pockels cell. For imaging, we used ScanImage software (Pologruto et al., 2003) written in MATLAB (Math- 
A

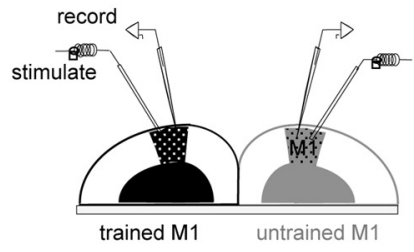

C

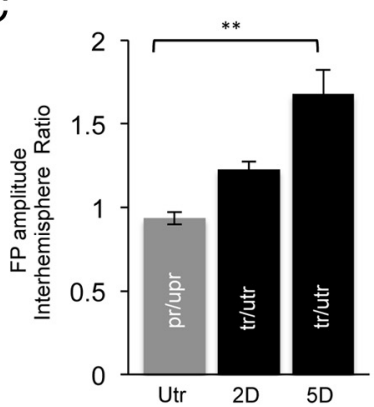

B

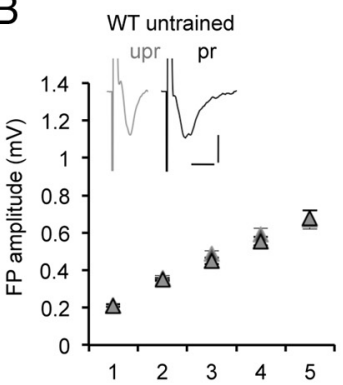

D

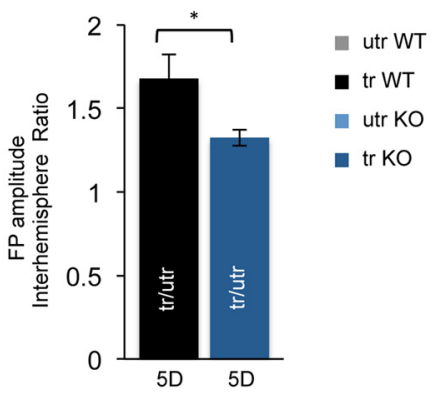

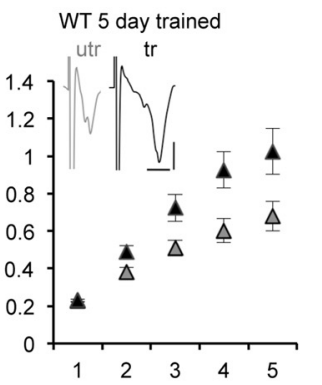

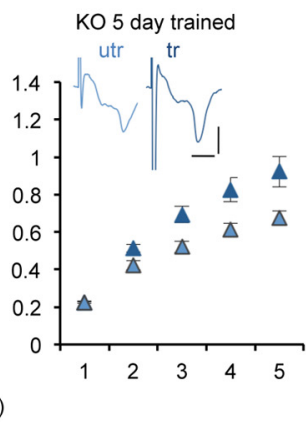

Threshold Factor (Stimulus Intensity)

utr WT

$\operatorname{tr} \mathrm{KO}$

Figure 2. Reduced synaptic strengthening with motor skill learning in the fmr $1 \mathrm{~K} 0$ mouse. $A, A$ schematic diagram of the slice recording from the forelimb $\mathrm{M} 1 \mathrm{in}$ the trained and untrained hemispheres. $\boldsymbol{B}$, Input- output curves in the preferred (pr) and unpreferred (upr) M1 of untrained WT mice and in the $5 \mathrm{~d}$ trained (tr) and untrained (utr) M1 hemispheres from WT and K0 mice. Inset, Representative evoked field potential responses in layer $2 / 3 \mathrm{M} 1$. Scale bar: $0.4 \mathrm{mV}, 5 \mathrm{~ms}$. C, Mean interhemisphere ratio of FP amplitude at threshold factor 4 in the untrained WT mice (gray, $n=$ 5), WT mice trained for 2 or $5 \mathrm{~d}$ (black, $n=4$ and $n=10$, respectively). $\boldsymbol{D}$, Mean FP amplitude interhemisphere ratio after $5 \mathrm{~d}$ of training in the WT and fmr $1 \mathrm{KO}$ mice (blue, $n=16$ respectively). Mean \pm SEM; ${ }^{*} p<0.05,{ }^{* *} p<0.01$.

Works). During an imaging session, five to six regions of interest (ROIs) per animal were selected along the dendritic tufts of YFP-expressing layer 5 pyramidal neurons. All imaged dendrites were in layer 1 (within the first $100 \mu \mathrm{m}$ below the dura mater) within the forelimb M1, as determined by stereotaxic measurements. Each ROI consisted of a stack of images (20-80 optical sections, separated axially by $0.48 \mu \mathrm{m})$. Each optical section was collected at $512 \times 512$ pixels, $0.13 \mu \mathrm{m} /$ pixel. The coordinates of each ROI were recorded using the XYZ motor on the MOM for subsequent imaging days.

Image analysis. Dendritic spine analysis was performed using ImageJ software. Dendritic segments, $20-60 \mu \mathrm{m}$ in length, were identified in three-dimensional image stacks taken at different time points, and all dendritic protrusions were marked and numbered. Dendritic filopodia were distinguished as long dendritic protrusions with no head, and were excluded from analysis $(<3 \%$ in both genotypes). Images were compared with that of the previous imaging session. Dendritic spines were analyzed by scrolling through individual $z$-planes within a stack. Dendritic spines were considered stable when they were present in the previous imaging session to the one being analyzed, eliminated when they appeared in the previous image but not in the image being analyzed, and newly formed when they appeared in the image being analyzed but not in the previous image. The percentage of spine formation and spine elimination was calculated by comparing the number of newly formed or eliminated spines to the total number of spines analyzed in the image, respectively. Protrusion turnover was defined as the sum of the protrusions lost and gained divided by twice the total protrusion number (Holtmaat et al., 2005). Analysis was performed on raw unprocessed images. For presentation purposes, images were despeckled and axons traversing the field of view were removed from some planes before maximum intensity projection of 3-15 planes of focus.

Statistics. Data are reported as mean \pm SEM. Normal distribution was tested using Kolmogorov-Smirnov test and variance was compared. Analysis was done either using two-sided unpaired Student's $t$ test or with one- or two-way ANOVA with the Bonferonni method for post hoc multiple comparisons. Data were analyzed using the GraphPad Prism or SAS/STAT software.

\section{Results}

Fmr1 KO mice show a deficit in a motor skill learning task

Five-week-old male fmrl KO $(n=38)$ and littermate WT mice $(n=36)$ were trained to reach through a small slit and grasp a food pellet using their preferred forelimb (Fig. 1A). Although the success rate, defined as proportion of successful retrieves from total reaches, of both the KO and WT mice increased over subsequent days of training, the $\mathrm{KO}$ mice achieved a lower success rate (Fig. $1 B$ ). Both genotype and days of training affect success rate $(p<0.01$, two-way repeated-measures ANOVA). Significant differences were observed on day 3 (WT, $0.44 \pm 0.02 ; \mathrm{KO}, 0.35 \pm$ $0.02, p=0.002)$, and day 5 (WT, $0.46 \pm 0.01 ; \mathrm{KO}, 0.39 \pm 0.02$, $p=0.034$; Fig. $1 B$ ). Additional training days did not lead to increased success rate in the KO mice (Day 6, $0.36 \pm 0.03$; Day 7, $0.38 \pm 0.03$; Day $8 \mathrm{KO}, 0.39 \pm 0.03, n=7)$. The success rate on the first day of training (WT, $0.28 \pm 0.02 ; \mathrm{KO}, 0.25 \pm 0.02, p>$ 0.99 ) as well as total number of reaching attempts made each day (Fig. 1C), were not significantly different between the WT and $\mathrm{KO}$ mice. These data indicate that the fmrl KO mice display a motor skill learning impairment that is not due to a basic motor function deficit.

\section{Reduced synaptic strengthening with motor skill training in the fmr $1 \mathrm{KO}$ mouse}

We next examined the synaptic mechanisms that might underlie this learning deficit. Previous experiments demonstrated that learning a motor skill task leads to strengthening of intracortical connections in layers 1 and $2 / 3$ of rat M1 (Rioult-Pedotti et al., 1998; Harms et al., 2008). To determine whether the motor skill learning deficit observed in the $\mathrm{fmr} 1 \mathrm{KO}$ mice is accompanied by a reduced synaptic strengthening, we measured the strength of intrinsic horizontal synaptic connections within layers $2 / 3$ in cor- 
A

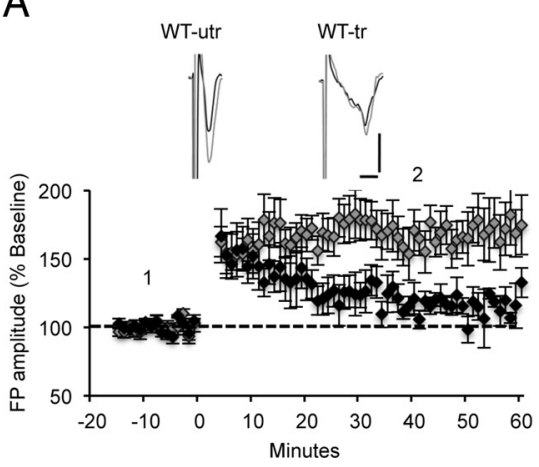

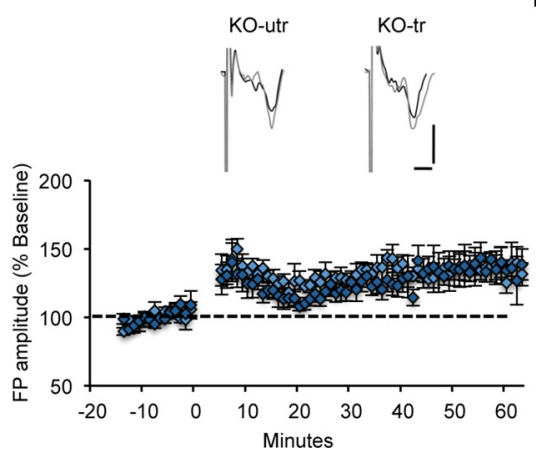

B

Figure 3. Absence of training-induced occlusion of cLTP in the M1 of the fmr $1 \mathrm{~K} 0$ mouse. $A$, Average time course of the change in FPs after cLTP. Representative FPs (average of 5 traces) with the black and gray traces taken before (1) and after (2) CLTP, respectively (time points indicated on the graph). In the WT mice, CLTP is occluded in the trained hemisphere (black, $n=5$ slices) compared with the untrained hemisphere (gray). In the fmr $1 \mathrm{KO}$ mice, no occlusion of CLTP is detected in the trained hemisphere (dark blue, $n=6$ slices) compared with the untrained hemisphere (light blue). Scale bars: $0.4 \mathrm{mV}, 5 \mathrm{~ms}$. $\boldsymbol{B}$, Average FPs $30-40 \mathrm{~min}$ after initiation of cLTP induction. Mean \pm SEM. The interaction between genotype and training on cLTP was significant $(p=0.022$, two-way ANOVA); ${ }^{*} p<0.05,{ }^{* *} p<0.01$.

onal brain slices containing both hemispheres (Fig. 2A). FP responses evoked in the horizontal pathway by electrical stimuli were examined in both hemispheres by placing stimulating and recording electrodes in layer $2 / 3$ of the left and right M1 (Fig. 2A). Stimulation evoked an initially negative-going field potential, as was previously described in rats (Hess et al., 1996). Consistent with previous reports (Rioult-Pedotti et al., 1998), in untrained control WT mice, the FP amplitudes evoked in the preferred hemisphere was not different from in the unpreferred hemisphere at all stimulation intensities (Fig. 2B). With training, in the WT mice the FP amplitudes evoked in the trained hemisphere were larger than those of the untrained hemisphere at different stimulation intensities (Fig. 2B). A gradual increase in the interhemisphere ratio of the FP amplitude, at threshold factor $4 \times$, was observed after 2 and $5 \mathrm{~d}$ of training compared with untrained mice (utr WT: $0.94 \pm 0.04, n=5$ mice; $2 \mathrm{~d}$ WT: $1.23 \pm 0.05, n=$ 4 mice, $p=0.5 ; 5 \mathrm{~d}$ WT: $1.68 \pm 0.15, n=10$ mice, $p=0.003$, one-way ANOVA; Fig. 2C). This suggests that the motor skill learning is associated with strengthening of synaptic connections in the trained M1 of WT mice. In the KO mice, the evoked FP was also larger in the trained hemisphere after $5 \mathrm{~d}$ (Fig. 2B). However, the interhemisphere ratio was lower after $5 \mathrm{~d}$ of training in the $\mathrm{KO}$ than the WT ( $5 \mathrm{~d}$ KO: $1.32 \pm 0.05, n=16$ mice, $p=0.012$, unpaired $t$ test; Fig. $2 D$ ). These data demonstrate that impaired motor skill learning in the $\mathrm{KO}$ is associated with attenuated synaptic strengthening.

\section{cLTP is impaired in the fmr1 KO mouse and is not occluded} with motor skill training

LTP is thought to be a cellular mechanism that strengthens synaptic connections and might underlie learning and memory in vivo. Indeed, motor skill learning has been shown to occlude LTP induction in the trained M1, suggesting that an LTP like mechanism is being used during learning (Rioult-Pedotti et al., 2000). Although long-term depression (LTD) has been shown to be exaggerated in the fmr1 KO mice (Huber et al., 2002) the role of FMRP in LTP is less clear (Li et al., 2002; Zhao et al., 2005; Lauterborn et al., 2007; Meredith et al., 2007; Hu et al., 2008). Moreover, the degree to which LTP is used during motor skill learning in the fmrl $\mathrm{KO}$ has not been examined.

To determine whether cLTP is impaired in the fmrl KO M1 and how it is modulated by motor skill learning, we trained mice on the forelimb reaching task and measured cLTP in trained and untrained hemispheres. To induce cLTP, slices were first exposed to bicuculline, as blocking GABAergic inhibition is necessary to induce other forms of LTP in M1 (Hess et al., 1996). Immediately thereafter, cLTP was induced with forskolin and rolipram in $\mathrm{Mg}^{2+}$-free ACSF, as previously described (Otmakhov et al., 2004). In the untrained hemisphere of WT mice, cLTP leads to a $169.8 \pm 14 \%$ increase of baseline response $(n=6$ slices from six mice), whereas in the fmrl $\mathrm{KO}$ the same protocol induced only $132.48 \pm 4.2 \%$ increase $(n=6$ slices from five mice, $p=0.026$, two-way ANOVA; Fig. $3 B$ ). We also determined whether motor skill training induces occlusion of cLTP in the trained hemisphere. In WT mice, we observed occlusion of cLTP in layer $2 / 3$ of the trained hemisphere (tr: $118.5 \pm 6.4 \% ; n=5$ slices from five mice, $p=0.003$, two-way ANOVA; Fig. $3 A, B$ ), similar to what was previously described (Rioult-Pedotti et al., 2000, 2007; Harms et al., 2008). In the fmrl KO mice though, no occlusion of cLTP was observed (tr: $127.33 \pm 8.3 \% ; n=6$ slices from five mice, $p=1$, two-way ANOVA; Fig. $3 A, B$ ). These data suggest that cLTP is attenuated in the fmrl $\mathrm{KO}$ and is not used during motor skill training to the same degree as in WT mice.

\section{Motor skill training-induced synaptic delivery of GluA1 is impaired in $\mathrm{fmrl} \mathrm{KO}$ mice}

Synaptic delivery of AMPA-type glutamate receptors is thought to be a major contributor to LTP (Malinow and Malenka, 2002). We therefore tested whether motor skill training induces translocation of AMPA receptor subunit GluA1 into synapses in the trained hemisphere and if it is impaired in the fmrl KO mouse. We first determined whether there was a difference in levels of synaptic GluA1 between the hemispheres before motor skill training. Crude synaptosomal preparations were isolated from the preferred (pr) and unpreferred (upr) M1 forelimb regions and synaptic GluA1 levels were determined using Western blot analysis (Fig. $4 A$ ). In the untrained WT mice (nonlittermate controls), there was no difference in synaptic GluAl between the hemispheres (pr: $0.78 \pm 0.1$; upr: $0.94 \pm 0.11 ; n=8$, unpaired $t$ test, $p=0.3$ ). This suggests that before training there is no increased synaptic GluA1 in the M1 forelimb region of the preferred hemisphere. We next trained the mice and isolated synaptosomes from the trained and untrained M1 forelimb regions at different times after training and determined the levels of synaptic GluA1. Although $2 \mathrm{~h}$ after training there was no difference in the interhemisphere ratio (trained/untrained) compared 
A

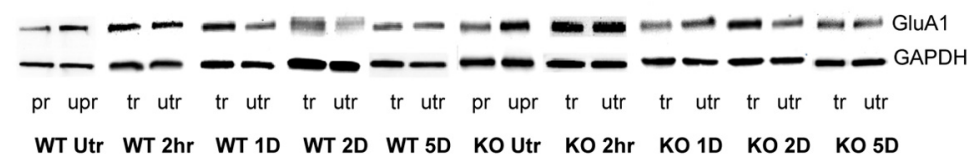

B

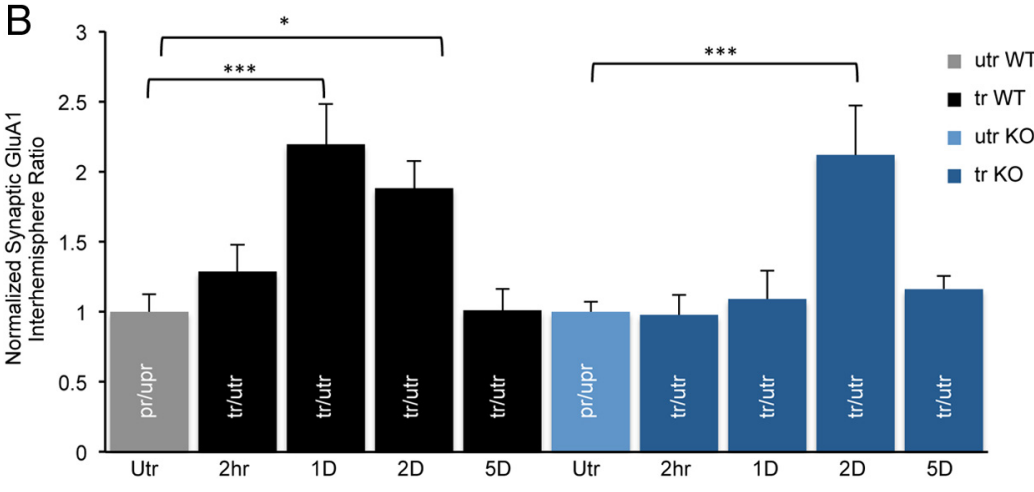

Figure 4. Learning induces a transient increase in synaptic GluA1 that is delayed in the fmr $1 \mathrm{KO}$ mouse. A, Western blots of synaptic GluA1 from forelimb M1 regions of preferred (pr) and unpreferred (upr) hemispheres from untrained (Utr) mice or from trained (tr) and untrained (utr) hemispheres of trained WT and fmr 1 K0 mice. $\boldsymbol{B}$, Untrained WT mice $(n=10)$ were compared with trained WT mice after $2 \mathrm{~h}(n=7), 1 \mathrm{~d}(n=14), 2 \mathrm{~d}(n=7)$, or $5 \mathrm{~d}(n=8)$ of training. Untrained K0 mice $(n=15)$ were compared with trained K0 mice after $2 \mathrm{~h}(n=7), 1 \mathrm{~d}(n=8), 2 \mathrm{~d}(n=9)$, or $5 \mathrm{~d}(n=7)$ of training. For quantification, protein levels were normalized to GAPDH and interhemisphere ratios were normalized to untrained WT or KO mice. Mean \pm SEM. The interaction between genotype and training on GluA1 interhemisphere ratio was significant ( $p=0.013$, two-way ANOVA); ${ }^{*} p<0.05$, ${ }^{* * *} p<0.001$.

with untrained mice (pr/unpr; utr: $1 \pm 0.12, n=10 ; 2 \mathrm{~h}$ tr: $1.29 \pm$ $0.19, n=7, p=1$, two-way ANOVA; Fig. $4 B), 1 \mathrm{~d}$ after training the interhemisphere ratio of synaptic GluA1 was significantly higher ( $1 \mathrm{~d}$ tr: $2.19 \pm 0.28, n=14, p<0.001$, two-way ANOVA; Fig. $4 B$ ). No difference was found between littermate controls and WT mice (data not shown); therefore, we combined these groups. These data suggest that motor skill training drives GluA1 to synapses. Because GluA1 translocation into synapses is transient with LTP and experience (Shi et al., 1999; Matsuo et al., 2008), we next examined synaptic GluA1 after 2 and $5 \mathrm{~d}$ of training. There was a gradual decrease in the interhemisphere ratio of synaptic levels of GluA1 ( $2 \mathrm{~d}$ tr: $1.9 \pm 0.19, n=7$ mice, $p=0.028$, two-way ANOVA) with no interhemisphere difference detected after five $\mathrm{d}$ of training $(5 \mathrm{~d}$ tr: $1.01 \pm 0.15 n=8$ mice, two-way ANOVA, $p=1$; Fig. $4 B$ ). Similar results were found when surface, rather than total synaptic levels of GluA1 were measured using a biotinylation method (utr: $1 \pm 0.11, n=7 ; 1 \mathrm{~d}$ tr: $2 \pm 0.34, n=$ $7, t$ test, $p=0.02$ ). These results suggest that motor skill training leads to a transient translocation of GluA1 into synapses.

In cortical neuronal cultures from fmrl $\mathrm{KO}$ mice, there is a deficit in GluA1 trafficking with LTP (Hu et al., 2008). Whether experience and learning in the fmr $1 \mathrm{KO}$ mouse result in impaired translocation of GluA1 into synapses in vivo is not known. We first compared basal synaptic levels of GluA1 in WT and KO untrained mice. No difference in levels of synaptic GluA1 were found between the genotypes of untrained mice (WT, $0.92 \pm$ $0.15, n=11 ; \mathrm{KO}, 0.86 \pm 0.09, n=8 ; p=0.78$, unpaired $t$ test). As in the WT, no increase in GluA1 was observed $2 \mathrm{~h}$ after motor skill training (utr KO, $1 \pm 0.07, n=15$ mice; 2 h KO, $0.98 \pm 0.14$, $n=7$ mice; $p=1$, two-way ANOVA,). Surprisingly, unlike in the WT mice, $1 \mathrm{~d}$ of motor skill training did not lead to increased synaptic expression of GluA1 in the trained hemisphere of the fmrl KO mice ( $1 \mathrm{~d} \mathrm{KO}, 1.09 \pm 0.2, n=8, p=1,2$-way ANOVA; Fig. $4 B$ ). We next examined whether there was a delay in synaptic translocation of GluA1 in the fmr $1 \mathrm{KO}$ mice. In mice trained for $2 \mathrm{~d}$, we observed an increase in levels of synaptic GluA1 in the trained hemisphere compared with untrained $\mathrm{KO}$ mice $(2 \mathrm{~d} \mathrm{KO}$,
$2.12 \pm 0.35, n=9, p<0.001$, two-way ANOVA). Similar to WT mice, the increase in synaptic GluA1, albeit delayed, was transient as no increase was observed in the trained hemisphere after $5 \mathrm{~d}$ of training $(5 \mathrm{~d} \mathrm{KO}, 1.21 \pm 0.1, n=7, p=1$, two-way ANOVA; Fig. 4B). These results suggest that in the fmrl KO mouse, there is a temporal impairment in the motor skill training-induced translocation of GluA1 into synapses that might contribute to the reduced learning in these mice.

\section{Normal density but higher turnover rate of dendritic spines in the fmrl KO mouse}

Because of the structure-function relationship of synapses, and in light of altered learning-induced synaptic plasticity, we next determined how synaptic structure and stability are altered in the fmrl KO mouse. Although altered dendritic spine morphology is a hallmark of FXS, the degree of spine abnormalities observed in the fmr1 KO mouse model is variable (He and Portera-Cailliau, 2013). To determine whether dendritic protrusions were altered in the primary motor cortex of fmrl KO mice, we crossed the fmrl KO mice with YFP-H mice and imaged the dendritic protrusions on apical tufts of layer 5 YFP-expressing neurons through a thinned skull window (Fig. 5). In 5-week-old untrained mice we observed no difference in the density of dendritic protrusions between the genotypes (WT: $0.38 \pm 0.03$ protrusions/micron, 1072 dendritic protrusions, $n=7$ mice; KO: $0.37 \pm 0.01$ protrusions $/ \mu \mathrm{m}, 1111$ dendritic protrusions, $n=8$ mice, $p=0.69$; Fig. $5 B$ ). The percentage of filopodia (defined as protrusions without spine heads and longer than $2.5 \mu \mathrm{m}$ ) was also not different in the $\mathrm{KO}$ mice (WT, $1.79 \pm 0.54 \%$; KO, $1.90 \pm 0.40 \%$; $p=0.87$; Fig. 5B). These data indicate that at this age there is no difference in total number of spines or filopodia in the apical tufts of layer 5 neurons in the M1 region.

Next, we asked whether the turnover rate of dendritic protrusions was altered in the fmrl $\mathrm{KO}$ mouse by imaging the same dendritic segments at $1 \mathrm{~d}$ intervals. Although we observed no difference in the total number of dendritic spines present after $1 \mathrm{~d}$ of imaging (WT: $97.9 \pm 0.57 \%$; KO: $97.6 \pm 0.82 \% ; p=0.67$ ), we did observe an increase in both the rates of dendritic spine formation (WT: $2.47 \pm 0.62 \%$; KO: $4.09 \pm 0.37 \%$; $p=0.037$; Fig. $5 C$ ) and dendritic spine elimination (WT:4.48 $\pm 0.55 \%$; KO: $6.54 \pm 0.71 ; p=0.043$; Fig. $5 C$ ) in the fmr $1 \mathrm{KO}$ mouse. Increased spine dynamics in the fmr $1 \mathrm{KO}$ mice was also observed by calculating the turnover ratio (TOR; WT: $0.034 \pm 0.005 ; \mathrm{KO}: 0.05 \pm$ $0.004 ; p=0.027$; Fig. $5 C$ ). The TOR for filopodia was much higher than for spines, but not different between the genotypes (WT: $0.7 \pm 0.07 ; \mathrm{KO}: 0.67 \pm 0.1 ; p=0.79$ ). These data suggest that 5 -week-old fmrl KO mice have an increased level of dendritic spine turnover in the apical tufts of layer 5 neurons in the M1.

Impaired formation of dendritic spines with motor skill training in the fmr $1 \mathrm{KO}$

Motor skill learning has been shown to affect dendritic spine formation and stability in the trained hemisphere (Harms et al., 2008; Xu et al., 2009). We next tested whether similar changes in 

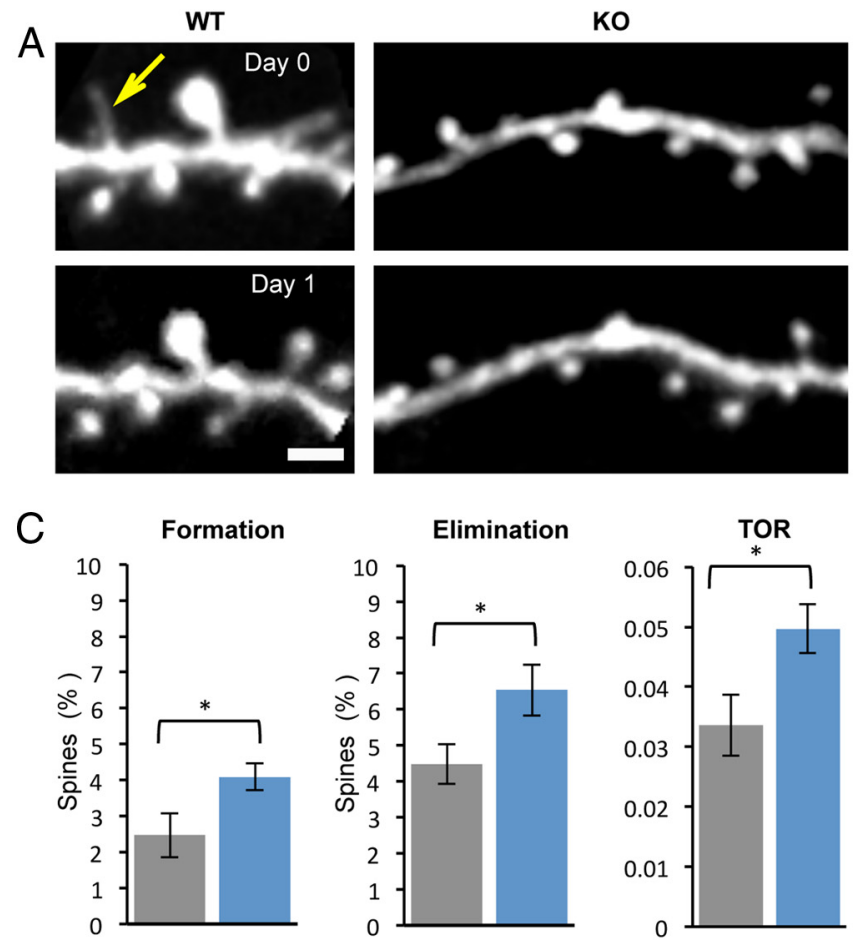

B
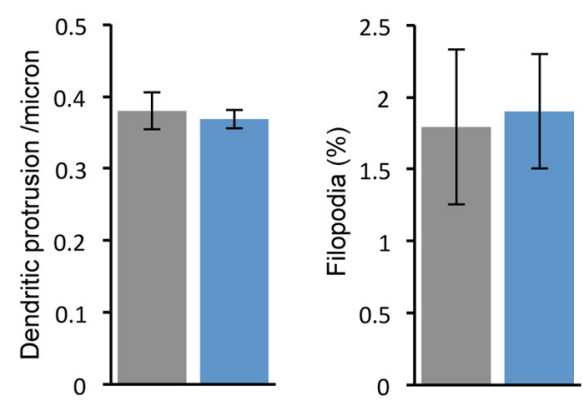

Figure 5. Normal density but higher turnover rate of dendritic spines in the fmr $1 \mathrm{KO}$ mouse. $A$, Multiphoton in vivo imaging of dendritic spines in layer 1 of Thy $1 \mathrm{YFP}$-H mice crossbred with fmr 1 KO mice. Imaging was performed on two consecutive days in untrained mice. Yellow arrow points to a filopodia that was lost on the second day of imaging. Scale bar, $3 \mu \mathrm{m}$. $\boldsymbol{B}$, Density of dendritic protrusion and percentage of filopodia were similar between the genotypes. C, Spine dynamics, measured as rates of spine formation, elimination, and TOR were higher in the KO mouse. WT ( $n=$ 7) and KO $(n=8)$ mice. Mean \pm SEM. ${ }^{*} p<0.05$.

dendritic spines are induced by motor skill learning in the fmr1 $\mathrm{KO}$ mouse. Dendritic spines were imaged in vivo to determine the baseline number of spines (Day 0; Fig. 6A). On the next day, mice were trained on the motor skill task and the same dendritic segments were reimaged $2-3 \mathrm{~h}$ following training (Day 1; Fig. 6A). A single hemisphere (either trained or untrained) was imaged in each mouse. As previously described, we find that in the WT mice motor skill training induced a rapid increase in number of dendritic spines in the trained hemisphere, compared with the untrained hemisphere (utr: $98.50 \pm 0.39 \%, 1532$ spines, $n=8$ mice vs tr: $104.96 \pm 1.31 \%, 905$ spines, $n=6$ mice; $p<0.001$, two-way ANOVA). The increase in total spines is mainly due to increased formation of spines (utr: $5.70 \pm 0.81 \%$ vs tr: $10.01 \pm 1.12 \%$; $p=$ 0.028 , two-way ANOVA), although a trend of reduced elimination of spines in the trained hemisphere was also observed (utr: $7.21 \pm 0.71 \%$ vs tr: $5.05 \pm 0.86 \% ; p=0.24)$. We next examined how spines change with motor skill learning in the fmrl $\mathrm{KO}$ mice (utr: 913 spines, $n=6$ mice; tr: 1769 spines, $n=8$ mice). The fmrl KO mice showed no significant difference between trained and untrained hemispheres in the rate of spine formation (utr: $7.17 \pm 1.06 \%$ vs tr: $6.71 \pm 1.21 \% ; p=1,2$-way ANOVA) and only a trend toward reduced elimination (utr $10.13 \pm 0.92 \%$ vs tr $7.44 \pm 0.82 \%, p=0.1$, two-way ANOVA). Consequently, we observed no substantial increase in the total number of spines with training (utr: $97.04 \pm 1.06 \%$ vs tr: $99.26 \pm 0.67 \%$; $p=0.23$, two-way ANOVA). These data imply that dendritic spine turnover in the fmr1 KO mice is less sensitive to motor skill training and might contribute to the reduced motor skill learning in these mice.

\section{Discussion}

Here we report that the fmrl $\mathrm{KO}$ mice display a deficit in learning a motor skill task. Analysis of motor skill training-induced func- tional, molecular, and structural synaptic changes demonstrate impairments in the fmr $1 \mathrm{KO}$ mouse. FP recordings from the forelimb M1 reveal attenuated training-induced synaptic strengthening, impaired levels of cLTP in the untrained hemisphere and reduced training-induced cLTP occlusion in the fmr $1 \mathrm{KO}$ mice. Although motor skill training induces a transient increase in synaptic levels of GluA1 in WT mice, a delay in GluA1 increase was observed in the trained hemisphere of the fmrl KO mice. Finally, using transcranial in vivo multiphoton microscopy we find that although spines are not altered in the fmr $1 \mathrm{KO}$ mouse, traininginduced formation of dendritic spines is impaired. We conclude that FMRP plays a role in motor skill learning and that reduced functional and structural synaptic plasticity might underlie the behavioral deficit in the fmrl KO mice.

The motor skill learning deficit reported here is consistent with mild behavioral impairments reported for the fmr $1 \mathrm{KO}$ mice (Consortium, 1994; D'Hooge et al., 1997; Dobkin et al., 2000; Budimirovic and Kaufmann, 2011; Krueger et al., 2011; Vinueza Veloz et al., 2012). We cannot exclude the possibility that other impairments in the fmrl $\mathrm{KO}$ mice, such as altered anxiety and activity levels, might affect motor skill learning. Nevertheless, reduced motor skill learning is not likely to be due to reduced motor performance or motivation because we observed a similar initial success rate as well as total number of reaching attempts made by the KO and WT mice. The absence of impairments in basic motor function in the fmr1 KO has also been previously reported (Wang et al., 2008; Vinueza Veloz et al., 2012). The impairment in motor skill learning we report here might be related to the motor skill impairments reported for FXS patients (Zingerevich et al., 2009; Van der Molen et al., 2010).

Experience-dependent regulation of synaptic strength is believed to be the physiological basis of learning and memory 
A
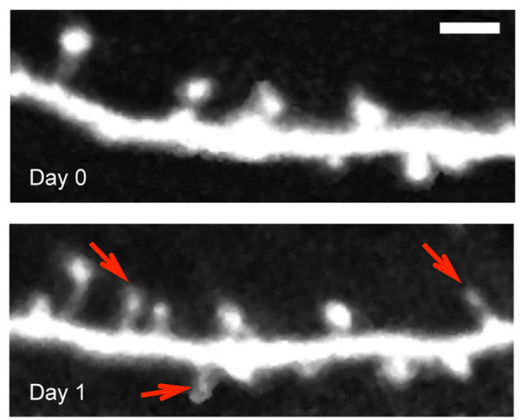

B

Botal

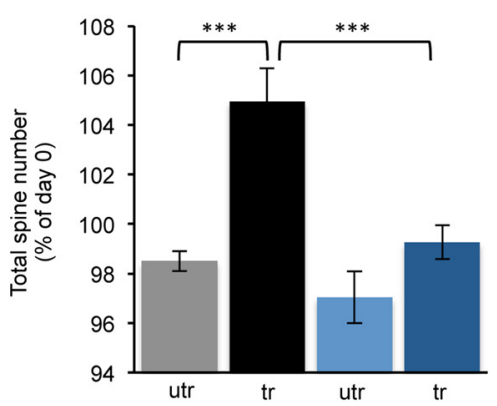

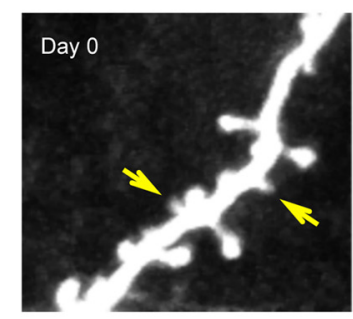

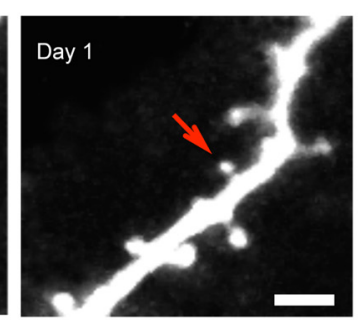

utr WT

- $\operatorname{tr} W T$

utr $\mathrm{KO}$

a $\operatorname{tr} K O$

Figure 6. Lack of motor learning induced increase in the number of dendritic spines in the fmr $1 \mathrm{KO}$ mouse. A, Multiphoton in vivo imaging of dendritic spines in layer 1 of Thy 1 YFP-H mice crossbred with fmr $1 \mathrm{KO}$ mice. Imaging was performed on two consecutive days with imaging performed $2-3 \mathrm{~h}$ after training on day 1 . New spines and lost spines are marked with red and yellow arrows, respectively. Scale bar, $3 \mu \mathrm{m}$. $\boldsymbol{B}$, After training the total spine number in the trained hemisphere of WT mice (black, $n=6)$ was higher than in the untrained hemisphere (gray, $n=8$ ), whereas in the KO mice there was no difference between trained (dark blue, $n=8$ ) and untrained hemispheres (light blue, $n=6$ ). In the WT mouse, the number of spines formed in the trained hemisphere exceeded the number of spines formed in the untrained hemisphere, whereas no differences were detected in the trained K0. A trend toward reduction in the number of eliminated spines was observed in the trained hemispheres of WT and KO mice. Mean \pm SEM. The interaction between genotype and training on total spines and spine formation was significant $(p=0.019$ and $p=0.036$, respectively, two-way ANOVA); ${ }^{*} p<0.05,{ }^{* * *} p<0.001$.

(Neves et al., 2008). Indeed, acquisition of a new motor skill is associated with enhancement of synaptic strength in the primary motor cortex as measured in slices (Rioult-Pedotti et al., 1998) and in vivo (Hodgson et al., 2005). Here, we observed that the same $5 \mathrm{~d}$ motor skill training regime resulted in less learning and attenuated synaptic strengthening in the trained hemisphere of the fmr $1 \mathrm{KO}$ mouse. Whether decreased learning-induced synaptic strengthening would be observed in vivo in the fmrl $\mathrm{KO}$ mice is not known. One mechanism for strengthening of synapses is LTP. Mechanisms similar to LTP have been postulated to be used during motor skill learning in vivo because the ability to induce LTP in the trained hemisphere is partially occluded in both slices and in vivo after training (Rioult-Pedotti et al., 2000, 2007; Hodgson et al., 2005; Harms et al., 2008). The reduced synaptic strengthening following training in the fmrl KO mouse could be partly due to impaired basal LTP or reduced ability to engage LTP-like mechanisms during training. Indeed, exaggerated mGluR-dependent LTD (Huber et al., 2002; Koekkoek et al., 2005) as well as impaired LTP (Desai et al., 2006; Meredith et al., 2007; Pfeiffer and Huber, 2009; Suvrathan et al., 2010), have been reported. Here we report that cLTP is also attenuated in the M1 of the fmr $1 \mathrm{KO}$ mouse. Although altered LTP in the cortex of fmr 1 $\mathrm{KO}$ mice was previously reported, to our knowledge this is the first report of reduced LTP in the primary motor cortex. We also found that CLTP is not occluded in the trained hemisphere of the fmrl $\mathrm{KO}$ as it is in WT mice. Although it is possible that we might have been able to detect occlusion with repeated cLTP induction, based on our present results we conclude that an LTP-like mechanism is not as readily engaged in the fmrl $\mathrm{KO}$ mouse during motor skill training.
A major molecular mechanism of LTP is the synaptic insertion of GluA1-containing AMPAR (Kessels and Malinow, 2009; Lee and Kirkwood, 2011). Synaptic insertion of GluA1 has been shown both with experience-dependent plasticity (Takahashi et al., 2003; Clem and Barth, 2006) and learning (Rumpel et al., 2005; Whitlock et al., 2006; Matsuo et al., 2008; Clem and Huganir, 2010). In fact, synaptic trafficking of AMPAR is thought to be necessary for some forms of learning (Rumpel et al., 2005). Although impaired AMPAR trafficking has been shown to mediate the LTP deficits in the fmr $1 \mathrm{KO}$ mice (Hu et al., 2008; Wang et al., 2008; Suvrathan et al., 2010), impaired experience or learning-induced GluA1 insertion in vivo has not been previously reported. Consistent with previous learning paradigms, we found that motor skill learning resulted in a transient increase in the synaptic surface GluA1 in the motor cortex. GluA1 levels increase in the trained hemisphere after $1 \mathrm{~d}$ of training and this increase gradually disappeared by day five. Interestingly, synaptic GluA1 insertion and structural synaptic plasticity occur at different time scales in vivo with GluA1 insertion being a later event. In the fmr 1 $\mathrm{KO}$ mice, motor skill training did not result in timely increase in synaptic GluA1. Instead, we observed that GluA1 levels were increased at the synapse only after $2 \mathrm{~d}$ of training. This temporal dysregulation of GluA1 insertion into synapses with motor skill learning might underlie the attenuated synaptic strengthening observed with training in the KO mice and ultimately the reduced learning.

Most excitatory synapses in the CNS form on dendritic spines (Gray, 1959), whose structure has been correlated to its function (Harris and Stevens, 1989; Matsuzaki et al., 2001; Bosch and Hayashi, 2012; but see, Lu et al., 2013). In many neurodevelop- 
mental disorders, including FXS, dendritic spines are more numerous and immature looking (Rudelli et al., 1985; Hinton et al., 1991; Irwin et al., 2001), but in studies of the fmr1 KO mouse, whether spine impairments were detected and the degree of the spine alterations varied according to brain region, developmental stage, and genetic background (Comery et al., 1997; Nimchinsky et al., 2001; McKinney et al., 2005; Grossman et al., 2006; Dölen et al., 2007; Pfeiffer and Huber, 2009; Cruz-Martín et al., 2010; Levenga et al., 2011; He and Portera-Cailliau, 2013). Our analysis demonstrates that at 5 weeks of age, there is no difference in the density of dendritic spines or filopodia in the apical dendrites of layer 5 pyramidal neurons in the $\mathrm{M} 1$ of $f m r 1 \mathrm{KO}$ mice. These data provide additional support to recent in vivo imaging studies that have failed to detect a difference in dendritic spine density (CruzMartín et al., 2010; Pan et al., 2010) in the fmrl KO mouse. Nevertheless, we do observe an increase in the rate of both formation and elimination of dendritic spines, but not filopodia, in the fmr $1 \mathrm{KO}$ mouse. This increase in dendritic spine turnover is similar to that seen by Pan et al. (2010) in the barrel cortex of postnatal day $30 \mathrm{fmr} 1 \mathrm{KO}$ mice, and is likely to underlie the impaired plasticity in the fmr $1 \mathrm{KO}$ mouse.

Long-lasting changes in synaptic activity are accompanied by alterations in spine shape, size, and number (Bosch and Hayashi, 2012). Recent studies have also produced a strong argument for the role of spines during the acquisition of new motor skills (Harms et al., 2008; Xu et al., 2009; Yang et al., 2009). Here we have found that the increase in the number of spines with motor skill learning that is observed in the WT mice is not detected in the $f m r 1 \mathrm{KO}$. We find that spine number increase after training is due to a combination of increased spine formation and decreased spine elimination in the trained hemisphere of WT mice although the difference in elimination was not significant. This is in contrast to $\mathrm{Xu}$ et al., 2009 that reported no training-induced decrease in spine elimination. This discrepancy could be due to differences in the design of the motor task. For example, the determination of the forelimb preference is shorter in our study making direct temporal comparisons between the studies difficult. Moreover, in our training box a gap exists between the platform where the food pellet is placed and the slit through which the mouse reaches out, making this a harder task. Nevertheless, the general finding of increased number of spines with training is consistent with previous reports. Importantly, in the $\mathrm{KO}$ mouse there is a lack of effect of training on spines, consistent with impairments in spine plasticity with sensory experience that have been previously described in the fmrl KO (Pan et al., 2010). Interestingly, we observed lower rates of spine formation and elimination in the untrained mice of both genotypes compared with untrained hemispheres of trained mice. A potential contributor to the difference in spine dynamics, in addition to the motor skill training itself, is that the trained mice were food restricted.

In summary, we have found a learning deficit in the fmr $1 \mathrm{KO}$ mouse and have determined that motor skill learning-induced changes in synaptic strength, synaptic GluA1 insertion and dendritic spine plasticity are all impaired in the $\mathrm{KO}$ mouse. These results suggest that reduced functional, molecular, and structural plasticity underlie the observed behavioral impairments in the fmr1 KO mouse.

\section{References}

Bosch M, Hayashi Y (2012) Structural plasticity of dendritic spines. Curr Opin Neurobiol 22:383-388. CrossRef Medline

Budimirovic DB, Kaufmann WE (2011) What can we learn about autism from studying fragile X syndrome? Dev Neurosci 33:379-394. CrossRef Medline
Clem RL, Barth A (2006) Pathway-specific trafficking of native AMPARs by in vivo experience. Neuron 49:663-670. CrossRef Medline

Clem RL, Huganir RL (2010) Calcium-permeable AMPA receptor dynamics mediate fear memory erasure. Science 330:1108-1112. CrossRef Medline

Comery TA, Harris JB, Willems PJ, Oostra BA, Irwin SA, Weiler IJ, Greenough WT (1997) Abnormal dendritic spines in fragile X knockout mice: maturation and pruning deficits. Proc Natl Acad Sci U S A 94:54015404. CrossRef Medline

Cruz-Martín A, Crespo M, Portera-Cailliau C (2010) Delayed stabilization of dendritic spines in fragile X mice. J Neurosci 30:7793-7803. CrossRef Medline

Darnell JC, Van Driesche SJ, Zhang C, Hung KY, Mele A, Fraser CE, Stone EF, Chen C, Fak JJ, Chi SW, Licatalosi DD, Richter JD, Darnell RB (2011) FMRP stalls ribosomal translocation on mRNAs linked to synaptic function and autism. Cell 146:247-261. CrossRef Medline

Desai NS, Casimiro TM, Gruber SM, Vanderklish PW (2006) Early postnatal plasticity in neocortex of Fmr1 knockout mice. J Neurophysiol 96: 1734-1745. CrossRef Medline

D’Hooge R, Nagels G, Franck F, Bakker CE, Reyniers E, Storm K, Kooy RF, Oostra BA, Willems PJ, De Deyn PP (1997) Mildly impaired water maze performance in male Fmr1 knockout mice. Neuroscience 76:367-376. CrossRef Medline

Dobkin C, Rabe A, Dumas R, El Idrissi A, Haubenstock H, Brown WT (2000) Fmrl knockout mouse has a distinctive strain-specific learning impairment. Neuroscience 100:423-429. CrossRef Medline

Dölen G, Osterweil E, Rao BS, Smith GB, Auerbach BD, Chattarji S, Bear MF (2007) Correction of fragile X syndrome in mice. Neuron 56:955-962. CrossRef Medline

Fu M, Yu X, Lu J, Zuo Y (2012) Repetitive motor learning induces coordinated formation of clustered dendritic spines in vivo. Nature 483:92-95. CrossRef Medline

Gernsbacher MA, Sauer EA, Geye HM, Schweigert EK, Hill Goldsmith H (2008) Infant and toddler oral- and manual-motor skills predict later speech fluency in autism. J Child Psychol Psychiatry 49:43-50. CrossRef Medline

Gray EG (1959) Axo-somatic and axo-dendritic synapses of the cerebral cortex: an electron microscopic study. J Anat 93:420-433. Medline

Grossman AW, Elisseou NM, McKinney BC, Greenough WT (2006) Hippocampal pyramidal cells in adult Fmr1 knockout mice exhibit an immature-appearing profile of dendritic spines. Brain Res 1084:158-164. CrossRef Medline

Harms KJ, Rioult-Pedotti MS, Carter DR, Dunaevsky A (2008) Transient spine expansion and learning-induced plasticity in layer 1 primary motor cortex. J Neurosci 28:5686-5690. CrossRef Medline

Harris KM, Stevens JK (1989) Dendritic spines of CA1 pyramidal cells in the rat hippocampus: serial electron microscopy with reference to their biophysical characteristics. J Neurosci 9:2982-2997. Medline

He CX, Portera-Cailliau C (2013) The trouble with spines in fragile X syndrome: density, maturity and plasticity. Neuroscience 251:120-128. CrossRef Medline

Hess G, Aizenman CD, Donoghue JP (1996) Conditions for the induction of long-term potentiation in layer II/III horizontal connections of the rat motor cortex. J Neurophysiol 75:1765-1778. Medline

Hinton VJ, Brown WT, Wisniewski K, Rudelli RD (1991) Analysis of neocortex in three males with the fragile X syndrome. Am J Med Genet 41:289-294. CrossRef Medline

Hodgson RA, Ji Z, Standish S, Boyd-Hodgson TE, Henderson AK, Racine RJ (2005) Training-induced and electrically induced potentiation in the neocortex. Neurobiol Learn Mem 83:22-32. CrossRef Medline

Holtmaat AJ, Trachtenberg JT, Wilbrecht L, Shepherd GM, Zhang X, Knott GW, Svoboda K (2005) Transient and persistent dendritic spines in the neocortex in vivo. Neuron 45:279-291. CrossRef Medline

Hu H, Qin Y, Bochorishvili G, Zhu Y, van Aelst L, Zhu JJ (2008) Ras signaling mechanisms underlying impaired GluR1-dependent plasticity associated with fragile X syndrome. J Neurosci 28:7847-7862. CrossRef Medline

Huber KM, Gallagher SM, Warren ST, Bear MF (2002) Altered synaptic plasticity in a mouse model of fragile X mental retardation. Proc Natl Acad Sci U S A 99:7746-7750. CrossRef Medline

Irwin SA, Patel B, Idupulapati M, Harris JB, Crisostomo RA, Larsen BP, Kooy F, Willems PJ, Cras P, Kozlowski PB, Swain RA, Weiler IJ, Greenough WT (2001) Abnormal dendritic spine characteristics in the temporal and vi- 
sual cortices of patients with fragile-X syndrome: a quantitative examination. Am J Med Genet 98:161-167. CrossRef Medline

Kessels HW, Malinow R (2009) Synaptic AMPA receptor plasticity and behavior. Neuron 61:340-350. CrossRef Medline

Koekkoek SK, Yamaguchi K, Milojkovic BA, Dortland BR, Ruigrok TJ, Maex R, De Graaf W, Smit AE, VanderWerf F, Bakker CE, Willemsen R, Ikeda T, Kakizawa S, Onodera K, Nelson DL, Mientjes E, Joosten M, De Schutter E, Oostra BA, Ito M, De Zeeuw CI (2005) Deletion of FMR1 in Purkinje cells enhances parallel fiber LTD, enlarges spines, and attenuates cerebellar eyelid conditioning in fragile X syndrome. Neuron 47:339-352. CrossRef Medline

Krueger DD, Osterweil EK, Chen SP, Tye LD, Bear MF (2011) Cognitive dysfunction and prefrontal synaptic abnormalities in a mouse model of fragile X syndrome. Proc Natl Acad Sci U S A 108:2587-2592. CrossRef Medline

Lauterborn JC, Rex CS, Kramár E, Chen LY, Pandyarajan V, Lynch G, Gall CM (2007) Brain-derived neurotrophic factor rescues synaptic plasticity in a mouse model of fragile X syndrome. J Neurosci 27:10685-10694. CrossRef Medline

Lee HK, Kirkwood A (2011) AMPA receptor regulation during synaptic plasticity in hippocampus and neocortex. Seminars in cell and developmental biology 22:514-520. CrossRef Medline

Levenga J, de Vrij FM, Buijsen RA, Li T, Nieuwenhuizen IM, Pop A, Oostra BA, Willemsen R (2011) Subregion-specific dendritic spine abnormalities in the hippocampus of Fmr1 KO mice. Neurobiol Learn Mem 95:467472. CrossRef Medline

Li J, Pelletier MR, Perez Velazquez JL, Carlen PL (2002) Reduced cortical synaptic plasticity and GluR1 expression associated with fragile X mental retardation protein deficiency. Mol Cell Neurosci 19:138-151. CrossRef Medline

Lu W, Bushong EA, Shih TP, Ellisman MH, Nicoll RA (2013) The cellautonomous role of excitatory synaptic transmission in the regulation of neuronal structure and function. Neuron 78:433-439. CrossRef Medline

Malinow R, Malenka RC (2002) AMPA receptor trafficking and synaptic plasticity. Annu Rev Neurosci 25:103-126. CrossRef Medline

Matsuo N, Reijmers L, Mayford M (2008) Spine-type-specific recruitment of newly synthesized AMPA receptors with learning. Science 319:11041107. CrossRef Medline

Matsuzaki M, Ellis-Davies GC, Nemoto T, Miyashita Y, Iino M, Kasai H (2001) Dendritic spine geometry is critical for AMPA receptor expression in hippocampal CA1 pyramidal neurons. Nat Neurosci 4:10861092. CrossRef Medline

McKinney BC, Grossman AW, Elisseou NM, Greenough WT (2005) Dendritic spine abnormalities in the occipital cortex of C57BL/6 Fmr1 knockout mice. Am J Med Genet B Neuropsychiatr Genet 136B:98-102. CrossRef Medline

Meredith RM, Holmgren CD, Weidum M, Burnashev N, Mansvelder HD (2007) Increased threshold for spike-timing-dependent plasticity is caused by unreliable calcium signaling in mice lacking fragile $\mathrm{X}$ gene FMR1. Neuron 54:627-638. CrossRef Medline

Neves G, Cooke SF, Bliss TV (2008) Synaptic plasticity, memory and the hippocampus: a neural network approach to causality. Nat Rev Neurosci 9:65-75. CrossRef Medline

Nimchinsky EA, Oberlander AM, Svoboda K (2001) Abnormal development of dendritic spines in FMR1 knock-out mice. J Neurosci 21:51395146. Medline

Otmakhov N, Khibnik L, Otmakhova N, Carpenter S, Riahi S, Asrican B, Lisman J (2004) Forskolin-induced LTP in the CA1 hippocampal region is NMDA receptor dependent. J Neurophysiol 91:1955-1962. CrossRef Medline

Pan F, Aldridge GM, Greenough WT, Gan WB (2010) Dendritic spine instability and insensitivity to modulation by sensory experience in a mouse model of fragile X syndrome. Proc Natl Acad Sci U S A 107:17768-17773. CrossRef Medline

Penagarikano O, Mulle JG, Warren ST (2007) The pathophysiology of fragile X syndrome. Annu Rev Genomics Hum Genet 8:109-129. CrossRef Medline

Pfeiffer BE, Huber KM (2009) The state of synapses in fragile X syndrome. Neuroscientist 15:549-567. CrossRef Medline

Pieretti M, Zhang FP, Fu YH, Warren ST, Oostra BA, Caskey CT, Nelson DL (1991) Absence of expression of the FMR-1 gene in fragile X syndrome. Cell 66:817-822. CrossRef Medline
Pologruto TA, Sabatini BL, Svoboda K (2003) ScanImage: flexible software for operating laser scanning microscopes. Biomed Eng Online 2:13. Medline

Rioult-Pedotti MS, Friedman D, Hess G, Donoghue JP (1998) Strengthening of horizontal cortical connections following skill learning. Nat Neurosci 1:230-234. CrossRef Medline

Rioult-Pedotti MS, Friedman D, Donoghue JP (2000) Learning-induced LTP in neocortex. Science 290:533-536. CrossRef Medline

Rioult-Pedotti MS, Donoghue JP, Dunaevsky A (2007) Plasticity of the synaptic modification range. J Neurophysiol 98:3688-3695. CrossRef Medline

Rudelli RD, Brown WT, Wisniewski K, Jenkins EC, Laure-Kamionowska M, Connel F, Wisniewski HM (1985) Adult fragile X syndrome cliniconeuropathologic findings. Acta Neuropathol 67:289-295. CrossRef Medline

Rumpel S, LeDoux J, Zador A, Malinow R (2005) Postsynaptic receptor trafficking underlying a form of associative learning. Science 308:83-88. CrossRef Medline

Shi SH, Hayashi Y, Petralia RS, Zaman SH, Wenthold RJ, Svoboda K, Malinow R (1999) Rapid spine delivery and redistribution of AMPA receptors after synaptic NMDA receptor activation. Science 284:1811-1816. CrossRef Medline

Shmuelof L, Krakauer JW (2011) Are we ready for a natural history of motor learning? Neuron 72:469-476. CrossRef Medline

Suvrathan A, Hoeffer CA, Wong H, Klann E, Chattarji S (2010) Characterization and reversal of synaptic defects in the amygdala in a mouse model of fragile X syndrome. Proc Natl Acad Sci U S A 107:11591-11596. CrossRef Medline

Takahashi T, Svoboda K, Malinow R (2003) Experience strengthening transmission by driving AMPA receptors into synapses. Science 299: 1585-1588. CrossRef Medline

Tennant KA, Adkins DL, Donlan NA, Asay AL, Thomas N, Kleim JA, Jones TA (2011) The organization of the forelimb representation of the C57BL/6 mouse motor cortex as defined by intracortical microstimulation and cytoarchitecture. Cereb Cortex 21:865-876. CrossRef Medline

The Dutch-Belgian Fragile X Consortium (1994) Fmrl knockout mice: a model to study fragile X mental retardation. Cell 78:23-33. CrossRef Medline

Van der Molen MJ, Huizinga M, Huizenga HM, Ridderinkhof KR, Van der Molen MW, Hamel BJ, Curfs LM, Ramakers GJ (2010) Profiling fragile $\mathrm{X}$ syndrome in males: strengths and weaknesses in cognitive abilities. Res Dev Disabil 31:426-439. CrossRef Medline

Vanvuchelen M, Roeyers H, De Weerdt W (2007) Nature of motor imitation problems in school-aged boys with autism: a motor or a cognitive problem? Autism 11:225-240. CrossRef Medline

Vinueza Veloz MF, Buijsen RA, Willemsen R, Cupido A, Bosman LW, Koekkoek SK, Potters JW, Oostra BA, De Zeeuw CI (2012) The effect of an mGluR5 inhibitor on procedural memory and avoidance discrimination impairments in Fmr1 KO mice. Genes Brain Behav 11:325-331. CrossRef Medline

Wang H, Wu LJ, Kim SS, Lee FJ, Gong B, Toyoda H, Ren M, Shang YZ, Xu H, Liu F, Zhao MG, Zhuo M (2008) FMRP acts as a key messenger for dopamine modulation in the forebrain. Neuron 59:634-647. CrossRef Medline

Weiler MH, Gundersen CB, Jenden DJ (1981) Choline uptake and acetylcholine synthesis in synaptosomes: investigations using two different labeled variants of choline. J Neurochem 36:1802-1812. CrossRef Medline

Whitlock JR, Heynen AJ, Shuler MG, Bear MF (2006) Learning induces long-term potentiation in the hippocampus. Science 313:1093-1097. CrossRef Medline

Xu T, Yu X, Perlik AJ, Tobin WF, Zweig JA, Tennant K, Jones T, Zuo Y (2009) Rapid formation and selective stabilization of synapses for enduring motor memories. Nature 462:915-919. CrossRef Medline

Yang G, Pan F, Gan WB (2009) Stably maintained dendritic spines are associated with lifelong memories. Nature 462:920-924. CrossRef Medline

Zhao MG, Toyoda H, Ko SW, Ding HK, Wu LJ, Zhuo M (2005) Deficits in trace fear memory and long-term potentiation in a mouse model for fragile X syndrome. J Neurosci 25:7385-7392. CrossRef Medline

Zingerevich C, Greiss-Hess L, Lemons-Chitwood K, Harris SW, Hessl D, Cook K, Hagerman RJ (2009) Motor abilities of children diagnosed with fragile X syndrome with and without autism. J Intellect Disabil Res 53:1118. CrossRef Medline 